\title{
Improvement of Mother Knowledge Who Have Children Age 2-5 Years About Training Toilet Using a Drawing Media
}

\author{
Abdul Haris ${ }^{1} \&$ A. Haris ${ }^{1}$ \\ ${ }^{1}$ Nursing Departement, Poltekkes Kemenkes Mataram, Indonesia \\ Corespondence: Abdul Haris and A. Haris, Nursing Departement, Poltekkes Kemenkes Mataram, Indonesia.
}

Received: May 10, 2019

Accepted: May 24, 2019

Online Published: May 28, 2019

doi:10.20849/ijsn.v4i2.575

URL: https://doi.org/10.20849/ijsn.v4i2.575

\begin{abstract}
Toilet training in children is an attempt to train children to be able to control urination and defecation. The purpose of this study was to find out the development of pictorial media as a learning method for mothers in training toilet training in children aged 2-5 years in the Work Area of Bolo Health Center, Bolo District, Bima Regency. The design of this study is "Pretest-Posttest, Control Group Design". The object of the study was 80 mothers who had children aged 2 - 5 years. Data were taken using the checklist sheet. To find out the results of the development of pictorial media as a learning method for mothers in training toilet training in children aged 2-3 years, the Wilcoxon test was performed by statistical tests. The results showed that the knowledge of mothers before toilet training through pictorial media was 29 people $(72.5 \%)$ lacked the knowledge and 11 people (27.5\%) had enough knowledge, after training, there were significant changes, 37 people (92.5) good knowledge and 3 people $(7.5 \%)$ enough knowledge. The conclusion of the pictorial media development training can increase maternal knowledge about toilet training in children aged 2-5 years in the Work Area of Bolo Community Health Center, Bolo District, Bima Regency.
\end{abstract}

Keywords: children age 2-5 years, drawing media, toilet training

\section{Introduction}

Toilet training in children is an attempt to train children to be able to control urination and defecation. Some experts argue that effective toilet training can be taught to children aged from 18 months to 3 years because children aged 18 months have language skills to understand and communicate (Azis Alimul, 2010).

States that through training toilets children will learn how they control the urge to urinate which in turn will make them accustomed to using the toilet (reflecting order) independently. The closeness of parent interaction with children in toilet training will make children feel safe and confident. According to the National Indonesian Household Health Survey in 2012, it is estimated that the number of children under five who are difficult to control bowel movements and bedwetting at the age of up to preschool reaches 75 million children. The phenomenon that occurs in the community, resulting from the toilet training concept that is not taught correctly can cause children cannot independently control defecation and urinate.

Knowledge about toilet training is very important for a mother to have. This will affect the implementation of toilet training in children. Mothers who have a good level of knowledge means having a good understanding of the benefits and effects of toilet training so that mothers will have a positive attitude towards the concept of toilet training (Suryabudhi, 2009).

In data collection in the working area of Bolo Health Center, Madapangga District, Bima Regency, it was found that the number of children aged 2 - 5 years was 749 people, with the initial data of children having problems with toilet training as many as 89 people. This data was taken randomly in 5 villages visited including Kananga Village, Leu Village, Darussalam Village, Timu Village, and Tumpu Village. In addition to preventing bedwetting and forming the act of clean and healthy living in children early in the toilet training will also form independence and self-confidence in controlling urination and defecation. Can train gross motor skills, namely by walking, sitting, squatting, standing and also fine motor skills, namely removing and wearing their own pants after urinating and defecating. And can also be used to train their intellectual abilities, namely children can imitate the right actions such as urinating and defecating in its place (Azis Alimul, 2010).

This toilet training is a moral exercise that is first accepted by children and is very influential on subsequent 
moral development. This is in line with Havighurt's opinion that toilet training is a moral exercise in shaping one's character (Suherman, 2000). Generally, toilet training teaching conducted by parents is $31 \%$ of parents begin teaching at the age of $18-36$ months, $27 \%$ start at $12-27$ months, and $16 \%$ at $28-32$ months and $22 \%$ at 32 months to the top. Parents wait for children to be taught toilet training so that teaching does not require a long time (Warner, 2007). Toddlers aged 3 years are also more prepared cognitively, psychologically, socially and emotionally for teaching toilet use. Statistical data shows that $90 \%$ of children between the ages of 18-36 months are successfully taught to use toilets with an average age of $27-28$ months, $80 \%$ of children get success not wetting the night between the ages of 30-42 months with an average age of 33 months (Wong, 2000).

The success of toilet training is not only from the physical, psychological and emotional abilities of the child itself but also from how the parents or mothers act to teach toilet training properly and correctly so that the child can do well and correctly until later (Warner, 2007). Practice or practice (practice) from mother's knowledge about toilet training, how to toilet training and what is needed in toilet training, after mothers know about toilet training, mothers must prepare themselves and toddlers for toilet training, expected after the mother understands and prepare for toilet training, mothers can practice what is known and prepared for toilet training (Wulandari, 2011).

Controlling defecation and bladder will cause bad things for children in the future if they are not accustomed. It can cause children to be undisciplined, spoiled, and the most important thing is that later on when children will experience psychological problems, children will feel different and cannot independently control large waste and urination (Azis Alimul, 2010).

\section{Method}

This research is a quantitative study with a type of Quasi-experimental research with a design "Pretest-Posttest, Control Group Design". By using this design the experimental group and the control group have the same characteristics. This study was conducted on mothers in the Bolo Community Health Center Bolo District Bima District from August to November 2018. The population in the study was each subject (for example humans, patients) who met the established criteria (Arikunto, 2008), so the number the population in this study in the Work Area of Bolo Health Center, Bolo Subdistrict, Bima Regency were 89 mothers who had children aged 2 - 5 years. Samples with Total sampling technique are one sampling technique where sampling techniques are the same as the population (Sugiyono, 2007). Inclusion criteria: All mothers who have children aged 2 - 5 years; All mothers who are carefully studied, All mothers can read and write. Exclusion criteria: Mothers who are not willing to be studied and Mothers who have mentally retarded children. The data obtained is included in the observation sheet. The collected data is then processed, which includes the identification of research problems with the Wilcoxon test statistical test. Statistical tests were used to test the comparative hypothesis of two correlated samples to determine the results of changes in the development of pictorial media as a learning method for mothers in training toilet training in children aged 2-5 years with a significance level of $\mathrm{P} \leq 0.05$.

\section{Discussion}

\subsection{Characteristics of Respondents}

Table 1. Frequency distribution based on maternal age in the work area of Bolo Community Health Center, Bolo District, Bima Regency in 2018

\begin{tabular}{lll}
\hline Age & Frequency & Percentage \\
\hline $\mathbf{2 0}-\mathbf{2 5}$ & 26 & $32.5 \%$ \\
$\mathbf{2 6}-\mathbf{3 0}$ & 25 & $31.2 \%$ \\
$>\mathbf{3 1}$ & 29 & $36.2 \%$ \\
\hline
\end{tabular}

Table 2. Frequency distribution based on maternal education in the work area of Bolo Community Health Center, Bolo District, Bima Regency in 2018

\begin{tabular}{lll}
\hline Education & Frequency & Percentage \\
\hline Elementary School & 2 & $2.5 \%$ \\
Senior high school & 0 & $0 \%$ \\
Junior high school & 74 & $92.5 \%$ \\
University & 4 & $5 \%$ \\
\hline
\end{tabular}


Table 3. Frequency distribution based on maternal occupation in the work area of Bolo Community Health Center, Bolo District, Bima Regency in 2018.

\begin{tabular}{lll}
\hline Occupation & Frekuensi & Persentase \\
\hline Housewife & 69 & $86.2 \%$ \\
Private & 11 & $13.8 \%$ \\
\hline
\end{tabular}

Table 4. Frequency distribution of maternal knowledge before and after picture media development for mothers about toilet training in the work area of Bolo Health Center, Bolo District, Bima Regency in 2018 in the treatment group

\begin{tabular}{lllll}
\hline Maternal Knowledge & Pre - Test & \multicolumn{3}{c}{ Post-Test } \\
\cline { 2 - 5 } & $\mathbf{F}$ & $\mathbf{\%}$ & $\mathbf{F}$ & $\mathbf{\%}$ \\
\hline High & 0 & 0 & 37 & 92.5 \\
\hline Moderate & 11 & 27.5 & 3 & 7.5 \\
\hline Low & 29 & 72.5 & 0 & 0 \\
\hline Total & 40 & 100 & 40 & 100 \\
\hline
\end{tabular}

There were 40 respondents experiencing changes in the ability to train children to be better with the average change was 20.50 and the Wilcoxon Signed Rank Test test results. Obtained probability value Sig. (2-tailed) of 0,000 with a value of $Z=-5,734$ that value is $<0.05$ so it is concluded that There is Development of pictorial media as a learning method for mothers in training toilet training in children aged 2-5 years

The results of the study obtained by the average researcher had less knowledge of as many as 29 people (72.5\%). And mothers with enough knowledge as many as 11 people $(27.5 \%)$ and after toilet training through pictorial media there was a significant change in which 37 women (92.5) and mothers with sufficient knowledge were as many as 3 people (7.5\%). Because mother's knowledge is still lacking.

This is possible because the mother did not understand and just heard the term toilet training. The mother's knowledge about toilet training is the extent to which the mother's knowledge of the way or process in which the mother helps the child to train defecation and small defects appropriately or the mother's understanding of understanding, methods or techniques for practicing defecation and urination, factors that influence and study of toilet training problems. Mother's knowledge about toilet training is the result of knowing and this happens after people do sensing a certain object. The mother's knowledge about toilet training has an impact on the mother's understanding of what actions should be taken in giving toilet training to her child. The level of knowledge of respondents about good toilet training is influenced by several factors, including the level of education and the presence of information from health workers. Toilet training in children is an attempt to train children to be able to control urination. In doing urination exercises in children need preparation. Through these preparations, it is expected that children can control urination independently. In teaching the practice of using the toilet, the right method or method is needed so that it is easily understood by children. The use of the right method will affect the success of parents, especially mothers in teaching the concept of toilet training in children. The method used in this study is the pictorial media method. Therefore, children will be trained to go to the toilet without having to use diapers or spreaders anymore (Albaramki, Allawama, \& Yousef, 2017).

This research is in accordance with the research conducted by Martaliana (2015) about increasing the ability to use the toilet through demonstration methods in children aged 4-5 years. With the results of research obtained after general data analysis, it can be concluded that in the first cycle of meetings 1 and 2, the increase in the ability to use the toilet through the demonstration method has not increased by the percentage of $10 \%$ to $20 \%$. Whereas in the second cycle of meetings 1 and 2 the increase in the ability to use the toilet through the demonstration method has increased by the percentage of $55 \%$ to $95 \%$. One of the factors that can encourage children's independence is parenting parents. Parents who always spoil their children will make children unable to be independent. Like wearing a diaper or pampers when traveling or while at home will result in children not being able to distinguish when it's time to urinate and big water and where when not. In this case, the role of the mother has a very strong influence in an effort to motivate the independence of children. One of them is through training using the toilet or often known as toilet training. Toilet training or exercise using the toilet is not a race but is a process of maturing for the child. In this study, the results obtained from mothers who received training on toilet training in children through pictorial media were able to change the habits of children who usually depend on the use of pampers starting independently even though they still need guidance from parents, 
especially mothers as the first role model of their children. Based on the results of the above research it can be concluded that demonstration is a very effective method because it helps children to know directly the learning process and to support the success of learning (Doan \& Toussaint, 2016).

The results of the study when measuring the ability of mothers to train children's training toilets were on average less as many as 32 people ( $8 \%$ ) and enough as many as 8 people $(20 \%)$ and carried out measurements without training toilet training with pictorial media knowledge of mothers did not change. This is because one of the factors that can encourage children's independence is parenting parents. Parents who always spoil their children will make children unable to be independent. Like wearing a diaper or pampers when traveling or while at home will result in children not being able to distinguish when it's time to urinate and big water and where when not. In this case, the role of parents has a strong influence in an effort to motivate the independence of children. One of them is through training using the toilet or often known as toilet training. Toilet training or exercise using the toilet is not a race but is a process of maturing for the child (Ardıç \& Cavkaytar, 2014).

The results of the study when measuring the ability of mothers to train children's training toilets were on average less as many as 32 people ( $8 \%$ ) and enough as many as 8 people $(20 \%)$ and carried out measurements without training toilet training with pictorial media knowledge of mothers did not change. This is because one of the factors that can encourage children's independence is parenting parents. Parents who always spoil their children will make children unable to be independent. Like wearing a diaper or pampers when traveling or while at home will result in children not being able to distinguish when it's time to urinate and big water and where when not. In this case, the role of parents has a strong influence in an effort to motivate the independence of children. One of them is through training using the toilet or often known as toilet training. Toilet training or exercise using the toilet is not a race but is a process of maturing for the child (Tarhan et al., 2015).

According to Hidayat (in Jane Gilbert, 2003), Toilet training is an attempt to train children to be able to control the urination (defecation) and defecation." According to Zaivera (in Jane Gilbert, 2003) "Toilet training is a teaching process for controlling defecation and defecation correctly and regularly." Unlike the opinion of the Counselor (in Jane Gilbert, 2003), "Toilet training is a habit of training defecation. "Based on the above understanding, it can be concluded that the definition of toilet training is a habitual effort to control urination (defecation) and defecation (BAB) regularly. According to Dyah Novieta (2000) in his book stated that there are several stages of training to use the potty, namely: a) Being optimistic. b) Choose the Right Position. c) Make Exercises Using the Potty Fun. When a child sits on a potty, look for something that's fun that can attract his attention. So that the child will continue to sit on the bedpan. d) Measure Time To Use The Pottle Carefully and e) Give Special Pants For Training. Teaching toilet training in children requires several stages such as getting used to using the toilet in children to urinate, by getting children into the toilet, children will adapt faster. Children also need to be trained to sit or in the toilet even with full clothing and explain to the child the use of the toilet. Do it regularly to the child when the child seems to want to urinate. "If the child is successful in toilet training, parents or teachers can give praise and do not blame if children cannot do it yet. Pambudi (in Jane Gilbert, 2003).

According to Bloom (in Notoadmodjo, 2003) states that "Children often refuse to do toilet training and hide from their parents." This happens according to the stage of development, then the child. Furthermore, according to Moeslichatoen (2004), argues "Picture is one vehicle to provide learning experiences so that children can master the subject matter better." Through children's demonstration activities are guided to use their eyes and ears in an integrated manner, so that the observations of the two senses can add mastery of the subject matter given. Martinis Yamin (2013) in his book states that "The use of demonstration methods can be applied provided that they have the expertise to demonstrate the use of tools or carry out certain activities such as actual activities. The researchers' assumption that the impact of the inability of mothers to train children to learn toilet training will cause children to continue to depend on using pampers that cause irritation and damage to children's skin due to the moisture of the pampers worn by children.

The results of the analysis of the average change of 40.50 and the Wilcoxon Signed Rank Test test results. Obtained probability value Sig. (2-tailed) of 0.000 that value $<0.05$ so it was concluded that there was Development of pictorial media as a learning method for mothers in training toilet training in children aged 2-5 years. Knowledge about toilet training is very important for a mother to have. This will affect the implementation of toilet training in children. Mothers who have a good level of knowledge means having a good understanding of the benefits and effects of toilet training so that mothers will have a positive attitude towards the concept of toilet training. Attitude is the tendency of mothers to act or behave (Ganda et al., 2015).

Habits that are wrong in controlling bowel movements and BAK will cause bad things for children in the future. It can cause children to be undisciplined, spoiled, and the most important thing is that later on when the child will experience psychological problems, the child will feel different and cannot independently control the large 
discharge and urinate (Rahayuningsih \& Rizki, 2014).

The concept of toilet training is not yet widely understood among the public, this is because the related information about toilet training is not generally introduced in the community while the phenomenon that occurs in the community as a result of the toilet training concept which is not taught correctly or incorrectly is very little because of the impact the negatives generated cannot be seen directly, this is what causes the concept of toilet training to be seen as not important in the development stage of toddler age children. Mother's knowledge about toilet training was also obtained from generation to generation from her parents. His childhood experience about toilet training obtained from his parents is one source of knowledge that can sustain a mother's level of knowledge about toilet training. This is as stated by Nasution (2000) which states that one of the factors that influence a person's knowledge is an experience (Tarhan et al., 2015). The factor of a mother's personal experience in training toilet training shapes their attitude towards management. Mothers who have previous experience tend to understand more about the benefits of the management carried out so that they tend to have a better attitude. For mothers who do not have prior experience, even though they have good knowledge of toilet training, there are certainly still doubts about the benefits of the management carried out, so they tend to be defensive or ask questions about the management, so this is perceived as a lack of attitude good in managing toilet training in toddler age children. The level of behavior of mothers in providing toilet training to toddler children is mostly good (83\%). Good maternal behavior in toilet training is demonstrated by the actions of mothers in training toilet training in children, namely how or techniques and actions of mothers in training toilet training in children aged 1-3 years. The good toilet behavior of mother training is influenced by various factors including maternal age, culture or habits in the community. The existence of culture or hygiene habits where one of them is doing toileting activities in the bathroom or toilet is a factor that influences the behavior of toilet training in mothers (Doan \& Toussaint, 2016).

\section{Conclusion}

Before the development of pictorial media, the average mother had less knowledge as many as 29 people (72.5\%). After toilet training was carried out through pictorial media, there was a significant change in which mothers with good knowledge amounted to 37 people (92.5\%). There is an increase in knowledge of mothers who have children aged 2-5 years about toilet training after being given the development of pictorial media as a learning method for mothers in training toilet training in children aged 2-5 years. Further research is needed in the development of toilet training pictorial methods by modifying the use of regional language and regional animation so that it can be applied to rural communities.

\section{References}

Albaramki, J. H., Allawama, M. A., \& Yousef, A. M. F. (2017). Toilet training and influencing factors that affect initiation and duration of training: A cross sectional study. Iranian Journal of Pediatrics, 27(3). https://doi.org/10.5812/ijp.9656

Ardıç, A., \& Cavkaytar, A. (2014). Effectiveness of the modified intensive toilet training method on teaching toilet skills to children with autism. Education and Training in Autism and Developmental Disabilities, 49(2), 263-276.

Arikunto, S. (2007). Prosedur Penelitian Suatu Pendekatan Praktek.Jakarta. PT RinekaCipta.

Doan, D., \& Toussaint, K. A. (2016). A parent-oriented approach to rapid toilet training. International Electronic Journal of Elementary Education, 9(2SpecialIssue), 473-486.

Ganda, D., Petrus, W., Bangsa, G., Christianna, A., Studi, P., Komunikasi, D., ... Petra, U. K. (2015). Perancangan Buku Interaktif Tentang Toilet Training Anak Usia 1-3 Tahun Abstrak Pendahuluan. Jurnal DKV Adiwarna. Retrieved from https://media.neliti.com/.../86704

Rahayuningsih, S. I., \& Rizki, M. (2014). Kesiapan Anak Dan Keberhasilan Toilet Training Di Paud Dan Tk Bungong Seuleupoek Unsyiah Banda ACEH Child Readiness and the Success of Toilet Training at Early Child Education and Kindergarten of Bungong Seuleupoek Banda Aceh. Idea Nursing Journal, 3(3), 274-284.

Tarhan, H., Çakmak, Ö., Akarken, İ., Ekin, R. G., Ün, S., Uzelli, D., ... Zorlu, F. (2015). Toilet training age and influencing factors: A multicenter study. Turkish Journal of Pediatrics, 57(2), 172-176.

\section{Copyrights}

Copyright for this article is retained by the author(s), with first publication rights granted to the journal.

This is an open-access article distributed under the terms and conditions of the Creative Commons Attribution license (http://creativecommons.org/licenses/by/4.0/). 